Nation, State and Empire in English

Renaissance Literature 



\title{
Nation, State and Empire in English Renaissance Literature
}

Shakespeare to Milton

\author{
Willy Maley
}

Department of English Literature

University of Glasgow

\section{palgrave




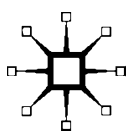

(c) Willy Maley 2003

Softcover reprint of the hardcover 1st edition 2003 978-0-333-64077-7

All rights reserved. No reproduction, copy or transmission of this publication may be made without written permission.

No paragraph of this publication may be reproduced, copied or transmitted save with written permission or in accordance with the provisions of the Copyright, Designs and Patents Act 1988, or under the terms of any licence permitting limited copying issued by the Copyright Licensing Agency, 90 Tottenham Court Road, London W1T 4LP.

Any person who does any unauthorized act in relation to this publication may be liable to criminal prosecution and civil claims for damages.

The author has asserted his right to be identified as the author of this work in accordance with the Copyright, Designs and Patents Act 1988.

First published 2003 by

PALGRAVE MACMILLAN

Houndmills, Basingstoke, Hampshire RG21 6XS and

175 Fifth Avenue, New York, N.Y. 10010

Companies and representatives throughout the world.

PALGRAVE MACMILLAN is the global academic imprint of the Palgrave Macmillan division of St Martin's Press, LLC and of Palgrave Macmillan Ltd. Macmillan ${ }^{\circledR}$ is a registered trademark in the United States, United Kingdom and other countries. Palgrave is a registered trademark in the European Union and other countries.

ISBN 978-1-349-39532-3

ISBN 978-1-4039-9047-1 (eBook)

DOI $10.1057 / 9781403990471$

This book is printed on paper suitable for recycling and made from fully managed and sustained forest sources.

A catalogue record for this book is available from the British Library.

Library of Congress Cataloging-in-Publication Data

Maley, Willy.

Nation, state, and empire in English Renaissance literature:

Shakespeare to Milton/Willy Maley.

p. $\mathrm{cm}$.

Includes bibliographical references (p. ) and index.

1. English literature - Early modern, 1500-1700 - History and criticism. 2. Nationalism and literature - Great Britain - History - 16th century. 3. Nationalism and literature - Great Britain - History - 17th century. 4. Shakespeare, William, 1564-1616 - Political and social views. 5. Milton, John, 1608-1674 - Political and social views. 6. Nationalism in literature. 7. Imperialism in literature. 8. State, The, in literature.

9. Renaissance - England. I. Title

PR428.N37 M35 2002

$820.9^{\prime} 358-\mathrm{dc} 21$

2002068341

$\begin{array}{llllllllll}10 & 9 & 8 & 7 & 6 & 5 & 4 & 3 & 2 & 1\end{array}$

$\begin{array}{llllllllll}12 & 11 & 10 & 09 & 08 & 07 & 06 & 05 & 04 & 03\end{array}$ 
For Andrew Hadfield - friend, Roman, countryman and lender of ears. 



\section{Contents}

Acknowledgements

ix

Foreword

John Kerrigan

xi

Introduction: Fostering Discussion - From the

Irish Question to the British Problem by

Way of the English Renaissance

1 'This Sceptred Isle': Shakespeare and the British Problem

2 Postcolonial Cymbeline: Sovereignty and

Succession from Roman to Renaissance Britain

3 Shakespeare, Holinshed and Ireland:

Resources and Con-texts

4 Forms of Discrimination in Spenser's

A View of the State of Ireland $(1596 ; 1633)$ :

From Dialogue to Silence

5 'Another Britain?' Bacon's Certain Considerations

Touching the Plantation in Ireland $(1606 ; 1657)$

6 Fording the Nation: Abridging History

in Perkin Warbeck (1633)

7 Milton's Observations (1649) and the

Complication of Interests' in Early Modern Ireland

Notes

Index 



\section{Acknowledgements}

Earlier versions of the named chapters appeared in the following publications, and the original editors and publishers are gratefully acknowledged.

Chapter 1 first appeared as "This Sceptred Isle": Shakespeare and the British Problem', in John Joughin (ed.), Shakespeare and National Culture (Manchester University Press, 1997; reprinted with the permission of Manchester University Press).

Chapter 2 first appeared as 'Postcolonial Shakespeare: British Identity Formation and Cymbeline', in Jennifer Richards and James Knowles (eds), Shakespeare's Late Plays: New Readings (Edinburgh University Press, 1999; reprinted with the permission of Edinburgh University Press).

Chapter 3 was first published as 'Shakespeare, Holinshed and Ireland: Resources and Con-texts', in Mark Thornton Burnett and Ramona Wray (eds), Shakespeare and Ireland: History, Politics, Culture (Macmillan, 1997).

The first section of Chapter 4 appeared as 'Dialogue-wise: Some Notes on the Irish Context of Spenser's View', in Connotations: A Journal for Critical Debate 6, 1 (1996/97), pp. 67-77, and an earlier version of the second section will be published as "This ripping of auncestors": The Ethnographic Present in Spenser's A View of the State of Ireland', in Philippa Berry and Margaret Tudeau-Clayton (eds), The Texture of Renaissance Knowledge (Manchester: Manchester University Press, 2003).

Chapter 5, “Another Britain?": Bacon's Certain Considerations Touching the Plantation in Ireland (1606)', appeared in Prose Studies: History, Theory, Criticism 18, 1 (1995; reprinted with the permission of Prose Studies and Frank Cass).

Chapter 6 appeared as 'Fording the Nation: The Abridgement of the British Problem in Perkin Warbeck (1633)', in Andrew Murphy (ed.), special early modern issue of Critical Survey 9, 3 (1997; reprinted with the permission of Critical Survey and Berghahn Books) (an earlier version had appeared as 'The Incorporation of Identities in Perkin Warbeck: A Response to Lisa Hopkins', 
in Connotations: A Journal for Critical Debate 7, 1 (1997/98), pp. 105-15).

Chapter 7 first appeared as 'Milton and "the Complication of Interests" in Early Modern Ireland', in Balachandra Rajan and Elizabeth Sauer (eds), Milton and the Imperial Vision (Pittsburgh, PA: Duquesne University Press, 1999; reprinted with permission of Duquesne University Press).

A version of Chapters 5 and 7 appeared in 'The British Problem in Three Irish Tracts by Spenser, Bacon, and Milton', in Brendan Bradshaw and Peter Roberts (eds), British Consciousness and Identity: The Making of Britain, 1533-1707 (Cambridge: Cambridge University Press, 1998; reprinted with permission of Cambridge University Press).

I would like to thank the two anonymous readers at Palgrave Macmillan who commented on successive drafts of this work. Due to pressures of time and space, I was able to respond more fully to the first than to the second, but that second reader can be sure that their stringent and sensitive suggestions will be taken on board for my next monograph. I owe heartfelt thanks to Becky Mashayekh at Palgrave Macmillan, who helped prise my fingers from the final typescript. 


\title{
Foreword
}

\author{
John Kerrigan
}

Where is Willy Maley coming from? A quick way to answer that question is to look at his address. 'Department of English, The University of Glasgow' it starts, and the mix of Irish and Scottish themes in his work (his sense of how significantly they interact) makes a lot of sense in the context of the city where he was born, brought up and teaches. Now that the Scots have their own parliament as well as their own legal system, football team and liking for Irn-Bru, anyone writing to Maley would be wise to put 'Scotland' after 'Glasgow G12 8QQ'. But Scotland has not yet wriggled out from under the thumb of Westminster, so that line in the address feels both supplementary and incomplete. The postman might not need much more help. But if you're writing from Tucson or Tokyo, should you add 'Great Britain' or 'United Kingdom' or both?

Addresses do not just specify what estate agents call 'location, location, location'. The alternative endings to Maley's address each proposes a different relationship with England, Wales and the divided territory of Ireland. They are fraught with politics, and, in the ceaselessly interactive regions of the North Atlantic littoral, that means fraught with history. Indeed, those competing addresses have a chronological as well as a geographical order. 'Scotland' was forged out of different peoples into an independent kingdom in the high Middle Ages (the Declaration of Arbroath, 1320, is often picked out as a decisive event), though it did not secure its present boundaries until the fifteenth century. 'Great Britain' acquired a regal existence in 1603, when James VI of Scotland came to the English throne, but the new entity did not develop much of an apparatus of statehood or cultural infrastructure until after the Treaty of Anglo-Scottish Union in 1707. As for 'United Kingdom', England/Wales and Scotland were declared a united kingdom in 1707, but rebellious Ireland was added in 1801, only for twenty-six of its counties to break away in 1922, leaving a large proportion of the population of the remaining six counties bidding to do likewise after 1968. 
In his research Maley has shed light on the confusions and contradictions generated by this process of geopolitical change by focusing on the literature and culture of a formative period: the late sixteenth and early seventeenth centuries. His first book - very much a precursor of the present work - was Salvaging Spenser: Colonialism, Culture and Identity (1997). With tremendous innovative brio, it broke away from the emphasis in Anglo-American scholarship on the moral allegory of The Faerie Queene, and brought out the importance of Ireland to a poet who left England and settled in Co. Cork. Before Salvaging Spenser, important work had been done by (chiefly Irish) historians on the nature of Elizabethan colonialism as it exploited both Munster and Virginia. As his subtitle suggests, Maley profited from this research. But he also triangulated Spenser between the three kingdoms of the early modern 'British Isles' and brought out the significance of Scotland to the poet's thinking about the English in Ireland.

This bold contribution to Spenser studies prepared Maley to make the link with the 'new British history' which underpins the present book. A few words of background are necessary. For generations, English historians had debated the causes of the civil wars of the 1640s. As Whig constitutional and Marxist economic explanations of the crisis were discredited, scholars began to look beyond England and to focus (in the late 1980s) on the so-called 'British problem': the difficulty of governing the three religiously and culturally heterogeneous kingdoms of the Stuart multiple monarchy in ways which did not generate concatenating instabilities. There were problems with 'the British problem', not least the fact that its exponents identified the Irish Rebellion of 1641 as a trigger of disaster but did not fit Ireland into their formulation. By not giving Ireland an address in the British problem, they failed adequately to address that problem. Whatever the drawbacks of the new British history, however, work on the early modern period has been galvanized by the changed agenda.

Willy Maley is only one of a number of scholars excited by the implications of this new British history for our understanding of Renaissance literature. Among those exploring the field are Andrew Hadfield, David Baker, Philip Schwyzer and myself. Journal articles and books are starting to fill the shelves. But Maley's Scottish-Irish axis makes him distinctively receptive to the new paradigm and 
alert to its limitations. When, in Nation, State and Empire in English Renaissance Literature, he looks at the British and Irish problematic as it develops from Spenser through Shakespeare to Ford and Milton, he does not just bring a fresh historical perspective to bear on familiar (and some strikingly unfamiliar) literary texts, but seeks to use the literature to correct the biases and blindspots of the historiography. True to his intellectual roots in the British Left (the Raymond Williams tradition), he brings out issues of class, violence and language, and is acutely self-aware about the implication of the new British history in devolutionary politics. He also concentrates on regions arguably under-analysed by cultural historians (though he in turn neglects Wales and matters Anglo-Welsh). Hence his attention to Ulster in the essays on Bacon and Milton. As a site where Scottishness, Irishness and Englishness met in the plantations of the early seventeenth century, this contested, bloodstained region became (as it has remained) a crucible of British identity formation.

Given Maley's interest in Ulster and colonialism in Ireland generally, it might seem strange for him to make so much use in this book of the language of postcolonial theory. How could Ireland be 'post-' something that was only just happening to it? As his vigilant, probing chapters on 'Shakespeare, Holinshed, and Ireland' and on Spenser's View of the State of Ireland bring out, the area around Dublin had been an Anglo-Norman colony since the thirteenth century, and a great deal of what was taken to be Irish by early modern English people had been brought to Ireland by their ancestors. Moreover, although the Old English descendants of the original colony remained attached to England and were regarded both by themselves and by many of the Gaelic Irish as culturally distinct, they were seen by the New English incomers of the Tudor period (neocolonialists in a postcolonial situation) as having 'degenerated' into Irish ways. So the Ireland described by Spenser's View resembles certain modern postcolonial societies in the sense that both the indigenous Irish and the Old English were busy hybridizing and imitating each other, developing modes of common existence under the shadow of an English polity that had culturally moved on.

If Willy Maley stopped there, this book would be less challenging. He also proposes, however, a postcolonial mentality in early modern England itself. When Henry VIII broke with the Roman Church, in the Act in Restraint of Appeals (1533), declaring 'this 
realm of England is an empire', he was initiating, Maley argues, an empire that 'copied (in true deconstructive fashion) the thing to which it was ostensibly opposed' (p. 35). To claim that the make-up of an expansionist Tudor England was 'copied' from the Roman empire of Julius Caesar and Augustus somehow transmitted through the medieval popes confounds too many variables, and it would be hard to substantiate from sixteenth-century sources. A clearer postcolonial moment might be found in the late thirteenth and early fourteenth centuries, when English writers chose to define their national identity against that of the Normans, who had invaded the country under William the Conqueror, at a time when English power was reaching into Ireland and Wales and claiming overlordship of Scotland. This quasi-postcolonial reaction against Norman occupation revived in the seventeenth century when those resisting arbritary authority and exploitative law called it 'the Norman Yoke'.

But Maley has a gift for skating on thin ice. He would rather provoke an argument than put criticism to sleep. So even if he exaggerates when he says that Shakespeare's 'England was caught between empires, Roman and British, as Ireland was in James Joyce's day' (p. 4) - exaggerates not least because, at this date, England was almost wholly Protestant - the intervention is far from fruitless. It can make us think differently about such texts as Spenser's Ruines of Time (1591) - not a work that Maley discusses - which is set among the ruins of the Roman city of Verulamium, later St Albans. This poem has some sympathy with the ancient British queen Boudicca, who led an anti-colonialist rebellion against the occupying Romans, and it mounts a critique of the vanities of Rome as a site of empire and false religion which carries over into a complaint against the vices of late Elizabethan England. Spenser believes that the English reformation was incomplete, leaving both church and state impregnated with the bad characteristics of Roman Catholicism, but as the poem builds there are suggestions of a larger assault on the nature of empire itself - its westward migration from Rome to Britain thoughts which go against the grain of Spenser's View.

As elsewhere with Maley, then, what looks like a polemical gesture turns out to change the way that we can read particular texts. But the example also points to a gap that can become an opportunity for other scholars. Although Nation, State and Empire notices how confessional allegiance figures in the conflicts in 
Ireland, it does not make much of religion. An account of the Act in Restraint of Appeals that recognised the centrality of ecclesiastical politics to sixteenth-century history would better support the idea that Tudor England was like Joyce's Ireland. It is worth remembering that the British problem in its classic, mid-seventeenth-century incarnation caught fire in 1637 when the Scots rejected a prayerbook that they thought too 'papistical' as well as too English, and that the Irish Rebellion of 1641 was driven, in large measure, by a desire to win back rights for the Catholic religion. When Maley writes about Milton's attack on the Belfast presbyterians in his Observations of 1649 , he is surely correct to make a connection with Anglo-Scottish politics, but the antagonism was more than political. Milton hated presbyterians because they wanted to deny liberty of worship to the independent sects in England.

In a rapidly developing new field, differences of emphasis are inevitable. And it is a genuine strength of this book that it makes you look for what it excludes. One way forward would be to devolve what it calls 'English Renaissance Literature'. Almost all the texts discussed in Nation, State and Empire were written within the sound of Bow Bells. It is time for poems, plays, romances and treatises produced in the English regions, including Cornwall, and from Scotland, Wales and Ireland, to be given fuller attention. The choice need not to be confined to those like Spenser, Barnabe Rich and Jeremy Taylor who went from England to the 'Celtic fringe'. There are plenty of significant figures born and bred outside England who have been either distortingly folded into Eng. Lit. or excluded from the category and left unread because their circumstances are relatively unfamiliar: William Drummond and Sir George Mackenzie (Lowland Scotland), Henry Vaughan (Breconshire), Richard Bellings (Leinster) and Roger Boyle, Earl of Orrery (Munster) to name but a few.

Then there is the question of the European context. Nation, State and Empire starts by discussing a revue that was staged in London in 1941 as a contribution to the war effort. Maley is struck by its opening speech, taken from Shakespeare's King John, which displays 'a siege mentality, England backed into a corner by Europe' (p. 8). It is true that, during Shakespeare's lifetime, many English people feared that the Catholic powers of Spain and France would use Ireland, Scotland and even Wales as badly guarded backdoors 
into England. But the isolationism can be overstated; and although Maley is right to say that the English lost a foothold on the continent when they ceded Calais in 1558, they soon became militarily involved in the Dutch rising against Spain in the Low Countries (where Elizabeth I was granted political rights). At the end of the period covered by this book, patriots like Cromwell were so sympathetic to the Dutch that a scheme for political union with England was put to the Netherlands in 1651. This initiative and its failure left its mark on the work of Milton and Marvell, as it did across the water on the Dutch and English poetry of Constantijn Huygens.

Yet although the centrifugal agenda of this book can stimulate the reader to go off at a tangent, its chief success is in being so direct and involving. Historically rich and trenchantly argued, it is also ebulliently verbal, seamed with irregular puns and riveted with punchy phrases. Few critics can match Willy Maley's combination of solid research and theoretical panache. Happy to explore an overdetermined work of the imagination such as Cymbeline, he is equally good (and this is rare) on political treatises. He shows how Bacon's 1609 Considerations and Milton's Observations grow in significance if we understand what authorities they were written for (king or commonwealth), the audiences they were aimed at (court élite or public), and the circumstances of their (instant or delayed) reception. Maley is alert to all sorts of unconsidered angles, but his attention is never merely local; he sets the stakes high, and brings the past and its sometimes obscure literature to life by making the reader recognise that we are caught in the same geopolitical flux as Spenser, Shakespeare, Ford, Bacon and Milton - that the present, like the early modern period, is a time of the breaking and making of nations.

Nation, State and Empire in English Renaissance Literature is an indispensable introduction to a topic whose moment has come. Its plentiful and hospitable footnotes give the reader a road-map of the scholarly resources available in the field, while its combative encounters with such luminaries as Stephen Greenblatt, Edward Said and Lawrence Stone put a clear line between inherited paradigms and the new British-Irish problematic. But the book is much more than a survey. Often highly original in its particular claims, it is written with a vitality that flows from Maley's understanding that 
to work in the field he has chosen is always a political act. This is so not just for those based in Britain and Ireland. Since we all have addresses, and are caught up in history and geopolitics, the implications of this book extend to Tucson and Tokyo. Maley makes his readers reflect on where they, as well as he, are coming from.

Liverpool, Cambridge, Co. Mayo 